\title{
Kajian Macam Pupuk Organik dan Jarak Tanam Terhadap Pertumbuhan dan Produksi Tanaman Jagung (Zea Mays L.)
}

\section{Study on the Types of Organic Fertilizers and Planting Spaces against the Growth and Production of Maize (Zea mays L.)}

\author{
Ana Amiroh, Seftiana Zahrotul Khumairoh, Istiqomah, dan Suharso \\ Fakultas Pertanian Universitas Islam Darul ‘Ulum Lamongan Jawa Timur \\ Korespondensi : seftianazahrotul845@gmail.com
}

\begin{abstract}
ABSTRAK
Penelitian ini dilaksanakan di Desa Dalegan Kecamatan Panceng Kabupaten Gresik. Yang memiliki ketinggian tempat \pm 6 meter diatas permukaan laut. Waktu pelaksanaan penelitian dilakukan pada bulan Januari sampai April 2019. Penelitian ini menggunakan Rancangan Acak Kelompok (RAK) Faktorial, yang terdiri dari dua faktor dan setiap faktor terdiri dari 3 level yaitu : macam pupuk organik dan jarak tanam. Faktor pertama, macam pupuk organik terdiri dari 3 level yaitu kontrol, pupuk kandang sapi, pupuk kandang ayam. Faktor kedua, jarak tanam yang terdiri dari 3 level yaitu $75 \times 20 \mathrm{~cm}, 60 \times 25 \mathrm{~cm}, 50 \times 30 \mathrm{~cm}$. Indikator pertumbuhan dan produksi yang diamati terdiri dari : tinggi tanaman, jumlah daun, panjang tongkol, diameter tongkol, berat biji kering, berat 1000 biji. Waktu pengamatan dilaksanakan mulai umur 28 hari dengan interval 14 hari sekali. Data hasil dari penelitian dianalisa menggunakan analisa sidik ragam dan dilanjutkan dengan Uji BNT 5\%. Hasil pengamatan dan perhitungan melalui analisa sidik ragam dapat diambil simpulan bahwa terdapat interaksi antara perlakuan pupuk kandang ayam dan jarak tanam $60 \mathrm{~cm} \times 25 \mathrm{~cm}$ terhadap pertumbuhan dan produksi tanaman jagung. Menunjukan pengaruh nyata terhadap tinggi tanaman umur 42 dan 56 hst, panjang tongkol, berat biji kering dan berat 1000 biji. Terdapat beda sangat nyata pada pengamatan tinggi tanaman umur 28 hst, jumlah daun 42 dan 56 hst, diameter tongkol. Terdapat tidak beda nyata pada pengamatan jumlah daun umur $28 \mathrm{hst}$.
\end{abstract}

Kata Kunci : Pupuk Organik, Jarak Tanam, Jagung.

\begin{abstract}
This research was conducted in Dalegan Village, Panceng District, Gresik Regency. Which has a place height of \pm 6 meters above sea level. The timing of the research was conducted from January to April 2019. This study used Factorial Randomized Block Design (RBD), which consisted of two factors and each factor consisted of three levels, namely: the type of organic fertilizer and spacing. The first factor, the type of organic fertilizer consists of 3 levels, namely control, cow manure, chicken manure. The second factor, the spacing consists of 3 levels, namely $75 \times 20 \mathrm{~cm}, 60 \times 25 \mathrm{~cm}, 50 \times 30 \mathrm{~cm}$. Indicators of growth and production observed consisted of: plant height, number of leaves, ear length, ear diameter, weight of dry seeds, weight of 1000 seeds. The time of observation is carried out starting at 28 days at intervals of 14 days. The results data from the study were analyzed using variance analysis and followed by a 5\% LSD Test. The results of observations and calculations through variance analysis can be concluded that there is an interaction between the treatment of chicken manure and spacing of $60 \mathrm{~cm} \times 25 \mathrm{~cm}$ on the growth and production of corn plants. It showed a significant effect on
\end{abstract}


plant age of 42 and 56 days, ear length, weight of dry seeds and weight of 1000 seeds. There is a very significant difference in the observations of plant height aged 28 days, number of leaves 42 and 56 days old, ear diameter. There was no significant difference in the observation of the number of leaves aged 28 days.

Keywords: Organic Fertilizer, Planting Distance, Corn.

\section{PENDAHULUAN}

Awal mula tanaman jagung (Zea mays L.) telah dikenal dan ditanam di Amerika Utara sejak 200 tahun sebelum masehi. Kemudian pada abad 17 bangsa Indian menanam tanaman jagung dijelajah oleh bangsa Eropa. Yang dikembangkan sebagai pakan ternak dan makanan pokok manusia. Pada era industrial, tanaman jagung diusahakan sebagai bahan baku penghasil minyak jagung dan dikembangkan sebagai bahan untuk pembuatan etanol. Ungkapan Sudarsana, (2000).

Jagung (Zea mays L.) merupakan salah satu tanaman pangan yang sangat disukai dan dikonsumsi masyarakat di Indonoesia. Tanaman jagung memiliki umur produksi yang lebih singkat. Bagi para petani tanaman jagung merupakan peluang usaha di pasar, karena memiliki nilai jual yang tinggi.

Di Indonesia sendiri pada tahun 2012 menepati peringkat ke-8 produsen jagung (pipilan kering) dunia. Provinsi penyumbang produksi jagung terbanyak adalah Jawa Timur yaitu 5 jt ton, Jawa Tengah 3,3 ton, Lampung 2,2 ton, Sulawesi Selatan 1,3 ton,Sumatra Utara 1,2 jt ton, Jawa Barat 700-800 jt ton, dan sisanya yang signifikan adalah NTT, NTB, Jambi dan Gorontalo. Rata-rata produksi jagung pertahun jagung nasional adalah 16 juta ton. (Anonimous, 2012).

Salah satu upaya yang dapat dilakukan untuk memberikan peningkatkan produksi tanaman dalam kegiatan budidaya yakni dengan cara pemupukan. Dan jenis pupuk yang dapat digunakan salah satunya berupa pupuk organik. Pemupukan ialah salah satu cara memperbaiki kesuburan tanah terhadap pertumbuhan dan produksi jagung. (Sutedjo, 2002) mengatakan bahwa petani berkelanjutan mengidentifikasi pupuk kandang sangatalah berpengaruh baik dengan keberhasilan suatu tanaman. Hal ini disebabkan karena unsur hara yang dibutuhkan tanaman cukup tersedia. Selain itu, pupuk kandang berpengaruh baik terhadap sifat fisik dan kimiawi tanah, mampu mendorong perkembangan jasad renik.

Disamping pemberian pupuk terhadap pertumbuhan tanaman jagung, untuk mendapatkan pertumbuhan dan produksi yang maksimal maka perlu diperhatikan hal serupa yang berkaitan dengan optimalisasi pupuk terhadap tanaman yakni jarak tanam. Hal ini dikarnakan ada beberapa faktor diantaranya adalah penyerapan unsur hara baik melalui daun ataupun akar serta intensitas sinar matahari pada stomata yang digunakan untuk proses fotosintesis yang saling membutuhkan untuk mengatasi kompetisi perebutan tersebut maka hendaknya perlu diberikan jarak tanam yang optimal agar tanaman dapat tumbuh dan berkembang serta produksi yang dihasilkan maksimal.

Tujuan penelitian ini untuk mengetahui pengaruh macam pupuk organik dan jarak tanam terhadap 
pertumbuhan dan produksi tanaman jagung (Zea mays L.)

\section{METODOLOGI PENELITIAN}

\section{Waktu dan Tempat}

Penelitian ini dilaksanakan di Desa Dalegan Kecamatan Panceng Kabupaten Gresik. Memiliki ketinggian tempat \pm 6 meter diatas permukaan laut. Waktu yang dilaksanakan pada bulan Januari sampai April 2019.

\section{Bahan dan Alat}

Bahan yang digunakan dalam penelitian ini terdiri dari benih jagung varietas BISI 79, pupuk kandang sapi, pupuk kandang ayam, skam, air, EM4, molase. Alat yang digunakan dalam penelitian ini meliputi alat tulis, cangkul, timbangan digital, meteran, gembor, jangka sorong, gelas ukur, papan nama, dan alat penunjang lainnya.

\section{Metode Penelitian}

Penelitian ini menggunakan Rancangan Acak Kelompok (RAK) Faktorial, yang terdiri dari dua faktor dan setiap faktor terdiri dari 3 level yaitu : macam pupuk organik dan jarak tanam. Faktor pertama, macam pupuk organik terdiri dari 3 level yaitu kontrol, pupuk kandang sapi, pupuk kandang ayam. Faktor kedua, jarak tanam yang terdiri dari 3 level yaitu $75 \times 20$ $\mathrm{cm}, 60 \times 25 \mathrm{~cm}, 50 \times 30 \mathrm{~cm}$.

\section{Pelaksanaan Penelitian}

\section{Pembuatan Pupuk Kandang Sapi}

Dalam hal ini, peneliti membuat sendiri pupuk kandang sapi mulai dari menyiapkan bahan sampai pupuk siap untuk digunakan.

Cara pembuatan : peneliti menyiapkan pupuk kandang sapi yang sudah matang (sudah lama) kemudian mencampur dengan EM4, molase dan skam. Lalu mencampur dan dijadikan satu semua bahan. Dan yang terakhir yaitu difermentasikan selama 2 minggu untuk mendapatkan hasil pupuk yang benarbenar matang sempurna. Sehingga pupuk siap untuk digunakan atau diaplikasikan ke tanaman yang digunakan peneliti.

Cara penggunaan pupuk kandang sapi :

- Diberikan sebanyak ( $9 \mathrm{~kg}$ ) untuk setiap petak tanaman dengan disebar merata. Apabila tanah kurang subur maka diberikan lebih.

- Untuk mencampurkan pupuk kandang sapi ke dalam tanah saat pengolaan lahan, tanah perlu dicangkul/bajak. Biarkan pupuk kandang sapi selama seminggu, setelah itu baru benih tanaman jagung ditanam.

\section{Pembuatan Pupuk Kandang Ayam}

Pupuk kandang ayam dibuat sendiri oleh peneliti dengan komposisi sebagai berikut : kotoran ayam, EM4, molase dan sekam.

Cara pembuatan : peneliti menyiapkan kotoran ayam yang sudah matang kemudian mencampur dengan EM4, molase dan skam. Setelah itu dicampurkan jadi satu dari semua bahan tersebut. Dan ditutup rapat untuk difermentasikan selama 2 minggu. Dan semingu sekali dibuka dan diaduk untuk mematangkan pupuk tersebut supaya benar - benar matang dan siap untuk diaplikasikan ke tanaman.

Cara penggunaan pupuk kandang ayam :

- Diberikan sebanyak ( $9 \mathrm{~kg}$ ) untuk setiap petak perlakuan, dengan disebar merata diatas permukaan tanah. Tanah yang kurang subur dapat diberikan perlakuan yang lebih. 
- Untuk mencampurkan pupuk kandang ayam ke dalam tanah sebelum tanam, tanah perlu dicangkul/bajak. Biarkan pupuk kandang sapi selama seminggu, setelah itu baru benih tanaman jagung ditanam.

\section{Pengolahan Tanah}

Pengolahan tanah dilakukan dengan cara pembajakan atau mencangkul, membuat saluran dan petakan, serta meratakan tanah. petakan dibuat dengan ukuran 3 meter $x 2$ meter.

Persiapan lahan untuk tanaman jagung sangat ditentukan oleh kondisi tanah sebelum penanaman, setiap jarak atau blok pada percobaan dibatasi dengan lebar $50 \mathrm{~cm}$ dan kedalamannya $20 \mathrm{~cm}$ sehingga bila hujan turun tanaman tidak akan terjadi genangan karena tanahnya sudah cukup baik untuk ditanami.

\section{Penanaman}

Membuat lubang tanaman dengan cara ditugal dengan kedalaman antara 5 $\mathrm{cm}$ setiap lubang diisi sebanyak 2 biji dan dilakukan penyulaman apabila terdapat beberapa tanaman yang tidak tumbuh, penanaman dilakukan dengan jarak tanam $75 \mathrm{~cm} \times 20 \mathrm{~cm}, 60 \mathrm{~cm} \times 25 \mathrm{~cm}$, dan $50 \mathrm{~cm} \times$ $30 \mathrm{~cm}$.

\section{Pemupukan}

Pemupukan pada lahan penelitian diberikan sekali sebelum tanam, dengan dosis pupuk kandang ayam dan kandang sapi masing-masing $9 \mathrm{~kg}$. Pemupukan dilakukan 7 hari sebelum tanam dengan cara ditugal disebelah tanaman dengan jarak $3 \mathrm{~cm}$ disebelah tanaman kemudian ditutup kembali.

\section{Pengairan}

Pada fase vegetatif tanaman sangat memerlukan air yang cukup untuk pembentukan biji dalam tongkol. Apabila tanaman kurang air maka akan mengalami kelayuan 1-2 hari.

Namun pada penelitian yang dilakukan, terjadi hujan yang sangat lebat dan pengairan pada tanaman terjadi drainase yang sangat buruk. Sehingga terjadi penurunan pada proses pertumbuhan tanaman. Drainase yang buruk diakibatkan karena berlebihnya air dan kurangnya pembuangan air yang cukup sehingga mengakibatkan tanaman terendam air hujan dan banyak mengalami kelayunan. Sehingga proses pertumbuhan tanaman jagung sedikit terganggu.

\section{Penyulaman}

Penyulaman dilakukan pada saat ada benih jagung yang tidak tumbuh, atau tumbuh abnormal dengan benih yang baru. Penyulaman dilakukan pada umur 7 hst agar pertumbuhan tanaman jagung dapat tumbuh secara merata.

\section{Penyiangan}

Penyiangan dilakukan secara manual yaitu dengan cara mencabut gulma disekitar tanaman jagung. Penyiangan dilakukan 2 kali yaitu penyiangan I dilakukan saat tanaman berumur 10 hari setelah tanam dan penyiangan II pada umur jagung 25 hari.

\section{$\begin{array}{lll}\text { Pengendalian OPT (organisme } & \end{array}$ Pengganggu Tanaman)}

Bila ada serangan organisme pengganggu tanaman dan diduga mengakibatkan kerusakan pada tanaman karena populasi hama maupun penyakit melampaui ambang batas pengendalian, maka sudah dipersiapkan pestisida sebagai pencegahan terhadap organisme pengganggu tanaman.

\section{Pemanenan}

Pemanenan jagung pada penelitian ini melakukan pemanenan masak secara 
fisiologis (masak tua, masak kerik/masak mati), yang ditandai dengan berangsurangsurnya batang, daun dan kelobot berwarna kuning.

\section{Pengeringan}

Pengeringan yang dilakukan adalah dengan penjemuran jagung dibawah terik matahari dengan cara dihamparkan diatas terpal.

\section{Parameter Pengamatan}

Pengamatan dilakukan pada masingmasing petak perlakuan dengan mengambil 5 tanaman sampel. Pengamatan dilakaukan pada umur 14 hari yang selanjutnya dengan interval 2 minggu sekali. Adapun parameter yang diamati yaitu : parameter pertumbuhan (fase vegetatif) dan fase produksi (fase generatif).

Tabel 1. Rata-rata Tinggi Tanaman (cm) Pada Umur 28 Hst, 42 Hst dan 56 Hst.

\begin{tabular}{lccc}
\hline \multirow{2}{*}{ Perlakuan } & \multicolumn{3}{c}{ Rata-rata Tinggi Tanaman (cm) pada Pengamatan } \\
& \multicolumn{3}{c}{ umur } \\
\cline { 2 - 4 } & $78 \mathrm{hst}$ & $42 \mathrm{hst}$ & $56 \mathrm{hst}$ \\
\hline $75 \mathrm{~cm} \times 20 \mathrm{~cm}+$ Kontrol & $78,40 \mathrm{~b}$ & $118,27 \mathrm{~d}$ & $143,00 \mathrm{~b}$ \\
$75 \mathrm{~cm} \times 20 \mathrm{~cm}+$ Pupuk Kandang Sapi & $118,13 \mathrm{~d}$ & $143,80 \mathrm{~b}$ \\
$75 \mathrm{~cm} \times 20 \mathrm{~cm}+$ Pupuk Kandang Ayam & $78,40 \mathrm{~b}$ & $119,27 \mathrm{bcd}$ & $142,80 \mathrm{~b}$ \\
$60 \mathrm{~cm} \times 25 \mathrm{~cm}+$ Kontrol & $78,73 \mathrm{~b}$ & $119,93 \mathrm{bc}$ & $143,33 \mathrm{~b}$ \\
$60 \mathrm{~cm} \times 25 \mathrm{~cm}+$ Pupuk Kandang Sapi & $78,60 \mathrm{~b}$ & $119,07 \mathrm{bcd}$ & $143,80 \mathrm{~b}$ \\
$60 \mathrm{~cm} \times 25 \mathrm{~cm}+$ Pupuk Kandang Ayam & $83,67 \mathrm{a}$ & $123,07 \mathrm{a}$ & $146,93 \mathrm{a}$ \\
$50 \mathrm{~cm} \times 30 \mathrm{~cm}+$ Kontrol & $78,40 \mathrm{~b}$ & $120,13 \mathrm{~b}$ & $142,80 \mathrm{~b}$ \\
$50 \mathrm{~cm} \times 30 \mathrm{~cm}+$ Pupuk Kandang Sapi & $78,80 \mathrm{~b}$ & $119,47 \mathrm{bcd}$ & $143,80 \mathrm{~b}$ \\
$50 \mathrm{~cm} \times 30 \mathrm{~cm}+$ Pupuk Kandang Ayam & $77,93 \mathrm{~b}$ & $119,53 \mathrm{bcd}$ & $142,33 \mathrm{~b}$ \\
\hline \multicolumn{1}{c}{ BNT 5\% } & 1,79 & 1,65 & 2,12 \\
\hline
\end{tabular}

Keterangan : Angka-angka yang diikuti oleh huruf yang sama dalam kolom yang sama tidak berbeda nyata dengan uji BNT 5\%.

Pada Tabel 1, dapat dilihat bahwa pengamatan prameter tinggi tanaman pada umur 28 hst terdapat berbeda sangat nyata dan pada umur 42,56 hst terdapat berbeda nyata pada perlakuan macam pupuk organik dengan hasil terbaik pada perlakuan pupuk kangan ayam dan jarak tanam $60 \mathrm{~cm} \times 25 \mathrm{~cm}$.

\section{Pengamatan dan Pengolahan Data}

Indikator pertumbuhan dan produksi yang diamati meliputi : tinggi tanaman, jumlah daun, panjang tongkol, diameter tongkol, berat biji kering, berat 1000 biji. Pengamatan dilaksanakan mulai umur 28 hari dengan interval 14 hari sekali. Data hasil penelitian dianalisa menggunakan analisa sidik ragam dan kemudian dilanjutkan dengan Uji BNT 5\%.

\section{HASIL DAN PEMBAHASAN}

\section{Tinggi Tanaman}

Hasil analisa sidik ragam menunjukkan interaksi pada perlakuan macam pupuk organik dan pengaruh jarak tanam terhadap pertumbuhan tinggi tanaman pada pengamatan umur 28, 42, dan 56 hst. selanjutnya dapat dilihat pada Tabel 1. 
x $25 \mathrm{~cm}$ memberikan hasil yang lebih biak dan lebih terlihat pengaruh beda nyata terhadap tinggi tanaman.

Pada Tabel 1. terdapat interaksi antara perlakuan macam pupuk organik dan jarak tanam pada parameter pengamatan tinggi tanaman umur 28,42 , dan 56 hst dengan perlakuan pupuk kandang ayam dan pengaruh jarak tanam $60 \mathrm{~cm} \times 25 \mathrm{~cm}$ memberikan hasil yang baik dan interaksi yang nyata terhadap tanaman jagung pada parameter tinggi tanaman. Hal ini diduga tanaman memerlukan unsur hara yang optimum pada masa menjelang pembentukan bunga dan interaksi cahaya yang cukup, yang bertujuan memperlancar proses metabolisme pada fase vegetaif menuju generatif.

Hal tersebut sama dengan pendapat Andoko (2012) yang menyatakan bahwa kebutuhan hara makro dan mikro dalam jumlah optimal akan mendorong pertumbuhan dan hasil tanaman menjadi lebih baik.

Pada saat umur tersebut adalah sudah memasuki masa generatif serta pemberian pupuk sangat terlihat berpengaruh memacu pertumbuhan, pada jarak tanam yang diduga sudah optimum kemungkinan untuk terjadinya kompetisi dalam penerimaan cahaya dan penyerapan air maupun unsur hara sangat kecil, sehingga sebelum kebutuhan tanaman akan cahaya, zat hara maupun air dapat terpenuhi. Hal ini berpengaruh pada fotosintesis, akibatnya akan berpengaruh pula pada pertumbuhan tanaman, sehingga tingginya hasil suatu varietas dikarenakan varietas tersebut mampu beradaptasi dengan lingkungan.

Meskipun secara genetik potensi varietas lain mempunyai hasil yang baik, tetapi masih dalam tahap adaptasi, maka hasilnya lebih rendah daripada yang seharusnya.

\section{Jumlah Daun}

Hasil analisa sidik ragam menunjukkan terdapat interaksi pada setiap perlakuan macam pupuk organik dan pengaruh jarak tanam terhadap pertumbuhan dan produksi tanaman jagung pada pengamatan parameter jumlah daun. Jumlah daun dapat dilihat pada Tabel 2.

Tabel 2. Rata-rata Jumlah Daun (helai) Pada Umur 28 Hst.

\begin{tabular}{cc}
\hline Perlakuan & Rata-rata jumlah daun (helai) umur 28 hst \\
\hline $75 \mathrm{~cm} \times 20 \mathrm{~cm}+$ Kontrol & $7.78 \mathrm{~b}$ \\
$75 \mathrm{~cm} \times 20 \mathrm{~cm}+$ Pupuk Kandang Sapi & $7.78 \mathrm{~b}$ \\
$75 \mathrm{~cm} \times 20 \mathrm{~cm}+$ Pupuk Kandang Ayam & $8.16 \mathrm{a}$ \\
\hline BNT 5\% & 0.33 \\
\hline
\end{tabular}


Tabel 3. Rata-rata Jumlah Daun (helai) Pada Umur 42 Hst dan 56 Hst.

\begin{tabular}{lcc}
\hline \multirow{2}{*}{ Perlakuan } & \multicolumn{2}{c}{ Rata-rata Jumlah Malai pada Pengamatan } \\
& \multicolumn{2}{c}{ umur } \\
\cline { 2 - 3 } & $42 \mathrm{hst}$ & $56 \mathrm{hst}$ \\
\hline $75 \mathrm{~cm} \times 20 \mathrm{~cm}$ + Kontrol & $11,47 \mathrm{c}$ & $15,00 \mathrm{~b}$ \\
$75 \mathrm{~cm} \times 20 \mathrm{~cm}+$ Pupuk Kandang Sapi & $11,93 \mathrm{~b}$ & $14,93 \mathrm{bc}$ \\
$75 \mathrm{~cm} \times 20 \mathrm{~cm}+$ Pupuk Kandang Ayam & $11,67 \mathrm{bc}$ & $14,87 \mathrm{bc}$ \\
$60 \mathrm{~cm} \times 25 \mathrm{~cm}+$ Kontrol & $11,47 \mathrm{c}$ & $15,00 \mathrm{~b}$ \\
$60 \mathrm{~cm} \times 25 \mathrm{~cm}+$ Pupuk Kandang Sapi & $11,60 \mathrm{bc}$ & $14,93 \mathrm{bc}$ \\
$60 \mathrm{~cm} \times 25 \mathrm{~cm}$ + Pupuk Kandang Ayam & $12,40 \mathrm{a}$ & $15,40 \mathrm{a}$ \\
$50 \mathrm{~cm} \times 30 \mathrm{~cm}+$ Kontrol & $11,67 \mathrm{bc}$ & $15,00 \mathrm{~b}$ \\
$50 \mathrm{~cm} \times 30 \mathrm{~cm}$ + Pupuk Kandang Sapi & $11,73 \mathrm{bc}$ & $14,87 \mathrm{bc}$ \\
$50 \mathrm{~cm} \times 30 \mathrm{~cm}$ + Pupuk Kandang Ayam & $11,53 \mathrm{bc}$ & $14,73 \mathrm{c}$ \\
\hline \multicolumn{1}{c}{ BNT 5\% } & 0,46 & 0,25 \\
\hline
\end{tabular}

Keterangan : Angka-angka yang diikuti oleh huruf yang sama dalam kolom yang sama tidak berbeda nyata dengan uji BNT 5\%.

Pada Tabel 2. dapat dilihat pada parameter pengamatan jumlah daun umur 28 hst terdapat pengaruh berbeda nyata pada perlakuan pupuk kandang ayam. Hal ini dikarenakan tanaman belum terlalu nampak persaingan antara tanaman baik daun ataupun akar dalam penyerapan unsur hara. Hal ini berpengaruh pada fotosintesis, akibatanya akan berpengaruh pula pada pembentukan tunas dan daun, sehingga jumlah daun pada tanaman akan bertambah dengan makin rendahnya populas (Basuki, 2000).

Pemupukan dengan pupuk kandang memiliki pengaruh yang nyata terhadap pertumbuhan tanaman jagung. Terutama pada perlakuan pupuk kandang ayam. Perlakuan tersebut dianggap bagus dibandingkan dengan perlakuan lainnya dikarena pupuk kandang ayam selalu memperbaiki respon tanaman yang baik karena relatif lebih efisien serta mempunyai unsur hara yang lebih dibandingkan dengan pupuk kandang lainnya.

Dan pada Tabel 3. pengamatan parameter jumlah daun umur 42 dan 56 hst terdapat pengaruh berbeda sangat nyata terhadap perlakuan jarak tanam dan pemberian pupuk organik. Dikarenakan pada umur tersebut tanaman mampu menyerap unsur hara dengan optimal dalam persaingan antar tanaman pada fase pertumbuhan dan pembentukan bunga setelah masa adaptasi terhadap lingkungan sangatlah kuat. Sehingga tanaman jagung mengalami pertumbuhan yang baik pada fase vegetatif menuju generatif. Dan perlakuan yang baik ditunjukan pada perlakuan pupuk kandang ayam dan jarak tanam $60 \mathrm{~cm} \times 25 \mathrm{~cm}$.

Supriono (2000) menyatakan, apabila suatu jarak tanam itu rapat, maka akan memepengaruhi pertumbuhan jumlah daun pada tanaman. Dikarena terjadi tumpang tindih daun tanaman yang menyebabkan pembentukan daun kurang maksimal dan terjadi perebutan unsur hara yang mampu menghambat pertumbuhan jumlah daun.

Tanaman yang hidup menggunakan karbohidrat untuk respirasinya. Pertumbuhan tanaman tergantung pada imbangan fotosintesis, yang membangun karbohidrat dan bahan tanaman dan respirasi yang menguraikan karbohidrat. 
Jika fotosintesis melebihi respirasi, seperti yang lazim terjadi pada tanaman yang sedang tumbuh, akan terjadi pertumbuhan. Akan tetapi pada kondisi yang kurang cahaya, respirasi mungkin sama dengan fotosintesis dan pertumbuhan akan terhambat. Hal ini terlihat pada hasil penelitian dimana jarak tanam yang lebih sempit mengakibatkan semakin sedikitnya jumlah daun yang terbentuk.

Bahan organik yang berasal dari sisa tanaman atau hewan seperti dalam bentuk pupuk kandang, pupuk hijau, kompos dan sebagainya. Sumber bahan organik darii

Tabel 4. Rata-rata Panjang Tongkol (cm) pupuk kandang mempunyai kandungan hara yang berbeda-beda tergantung dari berbagai macam hewan, umur hewan, macam makanan, dan penyiapan pupuk sebelum dipakai (Aini Indrasari, 2006). Penambahan perlakuan bahan organik lainnya dapat meningkatkan kapasitas serapan dari berbagai gugus fungsional yang dimilikinya.

\section{Panjang Tongkol}

Hasil analisa ragam menunjukkan terdapat interaksi pada perlakuan macam pupuk organik dan jarak tanam terhadap parameter pertumbuhan panjang tongkol. Panjang tongkol dapat dilihat pada Tabel 4.
Perlakuan

Rata-rata panjang tongkol $(\mathrm{cm})$

\begin{tabular}{|c|c|}
\hline $75 \mathrm{~cm} \times 20 \mathrm{~cm}+$ Kontrol & $26.33 c$ \\
\hline $75 \mathrm{~cm}$ x 20 cm + Pupuk Kandang Sapi & $26.40 \mathrm{c}$ \\
\hline $75 \mathrm{~cm}$ x $20 \mathrm{~cm}+$ Pupuk Kandang Ayam & $26.27 c$ \\
\hline $60 \mathrm{~cm} \times 25 \mathrm{~cm}+$ Kontrol & $26.47 \mathrm{bc}$ \\
\hline $60 \mathrm{~cm} \times 25 \mathrm{~cm}+$ Pupuk Kandang Sapi & $27.07 \mathrm{bc}$ \\
\hline $60 \mathrm{~cm} \times 25 \mathrm{~cm}+$ Pupuk Kandang Ayam & $28.60 \mathrm{a}$ \\
\hline $50 \mathrm{~cm} \times 30 \mathrm{~cm}+$ Kontrol & $26.67 \mathrm{bc}$ \\
\hline $50 \mathrm{~cm}$ x $30 \mathrm{~cm}+$ Pupuk Kandang Sapi & $26.67 \mathrm{bc}$ \\
\hline $50 \mathrm{~cm}$ x $30 \mathrm{~cm}+$ Pupuk Kandang Ayam & $27.27 a b$ \\
\hline BNT 5\% & 0.84 \\
\hline \multicolumn{2}{|c|}{$\begin{array}{c}\text { Keterangan : Angka-angka yang diikuti oleh huruf yang sama dalam kolom yang sama tidak } \\
\text { berbeda nyata dengan uji BNT } 5 \% .\end{array}$} \\
\hline $\begin{array}{l}\text { Pada Tabel } 4 . \text { pengamatan } \\
\text { parameter panjang tongkol tanaman } \\
\text { terdapat pengaruh beda nyata terhadap } \\
\text { pemberian macam pupuk organik dengan } \\
\text { perlakuan jarak tanam. Perlakuan yang } \\
\text { baik ditunjukkan pada pengaruh pupuk } \\
\text { kandang ayam dan jarak tanam } 60 \mathrm{~cm} \times 25 \\
\mathrm{~cm} \text {. }\end{array}$ & $\begin{array}{l}\text { perlakuan jarak tanam } 60 \mathrm{~cm} \times 25 \mathrm{~cm} \\
\text { dianggap baik untuk mendapatkan hasil } \\
\text { yang optimal. Dan tidak itu saja, dalam } \\
\text { setiap perlakuan memiliki kemampuan } \\
\text { untuk mempertahankan hidup dan } \\
\text { pertumbuhan, sehingga dalam hal ini } \\
\text { berpengaruh terhadap panjang tongkol } \\
\text { tanaman jagung. }\end{array}$ \\
\hline $\begin{array}{l}\text { Hal ini disebabkan karena dengan } \\
\text { diberikannya pupuk kandang ayam dan }\end{array}$ & $\begin{array}{c}\text { Perlakuan pupuk kandang ayam dan } \\
\text { jarak tanam yang diberikan, mampu }\end{array}$ \\
\hline
\end{tabular}


menyediakan unsur hara dan kompetisi yang terjadi masih mampu ditolerir oleh tanaman sehingga distribusi asimilat ketongkol cukup memadai untuk pertumbuhan tongkol. Rachman (2008) menyatakan, tanaman hanya menyerap hara yang di butuhkan dan sesuai dengan fungsi berdasarkan umur pertumbuhan tanaman.

Perlakuan pupuk kandang ayam pada pengaruh jarak tanam yang diberikan berbeda nyata terhadap panjang tongkol. Hal ini disebabkan pemberian pupuk kandang ayam sudah mampu memperbaiki sifat fisik, kimia dan biologi tanah selain itu media tanam juga sudah mampu mencukupi kebutuhan unsur hara khususnya unsur $P$, sehingga pertumbuhan tongkol tetap optimal. Hal ini diungkapkan oleh Sidar (2010), bahwa unsur $P$ sangat dibutuhkan tanaman jagung pada fase generatif dalam pembentukan tongkol.

Perlakuan jarak tanam menunjukkan berbeda sangat nyata terhadap panjang tongkol. Hal ini disebabkan tanaman menggunakan jarak tanam tidak terlalu rapat mampu mentolerir tingkat kompetisi dalam menggunakan unsur hara, air dan cahaya meskipun tongkol yang terbentuk memiliki ukuran sedikit lebih pendek. Hasil pengamatan pengaruh pupuk kandang ayam dan jarak tanam menunjukan panjang tongkol jagung lebih pendek. Diduga karena dalam hal ini pengaruh lingkungan yang mengakibatkan tanaman terserang penyakit yang mana mampu mempengaruhi pertumbuhan tanaman. Sehingga proses fotosintesis kurang optimal dan tingkat kompetisi mendapatkan unsur hara yang lebih tinggi tetapi masih mampu dalam pertumbuhan tongkol. Intensitas cahaya matahari yang berbeda menyebabkan terjadinya perbedaan pada parameter pertumbuhan yang berbeda pula pada tanaman.

Pertumbuhan panjang tongkol dipengaruhi oleh taraf perlakuan macam pupuk kandang. Pemberian jenis pupuk kandang ayam menunjukkan tongkol berkelobot yang lebih panjang dibandingkan dengan perlakuan pupuk kandang sapi dan tanaman tanpa perlakuan. Terdapatnya perbedaan ini karena pupuk kandang ayam menghasilkan unsur hara $\mathrm{N}, \mathrm{P}$, dan $\mathrm{K}$ lebih tinggi dari yang lainnya. Tingginya unsur fosfor akan mempunyai peranan yang lebih besar pada pertumbuhan generatif tanaman terutama pada pembungaan, pembentukan tongkol dan biji. Unsur P sangat dibutuhkan dalam membantu perkembangan sutu tanaman sehingga P-lah yang dianggap penting untuk menentukan mutu buah.

\section{Diameter Tongkol}

Hasil analisa sidik ragam menunjukkan terdapat pengaruh beda sangat nyata pada perlakuan macam pupuk organik dan perlakuan jarak tanam terhadap parameter diameter tongkol pada saat panen. Diameter tongkol jagung dapat dilihat pada Tabel 5. 
Tabel 5. Rata-rata Diameter Tongkol (cm)

\begin{tabular}{ll}
\hline \multicolumn{1}{c}{ Perlakuan } & Rata-rata diameter tongkol $(\mathrm{cm})$ \\
\hline $75 \mathrm{~cm} \times 20 \mathrm{~cm}+$ Kontrol & $4.64 \mathrm{~b}$ \\
$75 \mathrm{~cm} \times 20 \mathrm{~cm}+$ Pupuk Kandang Sapi & $4.72 \mathrm{~b}$ \\
$75 \mathrm{~cm} \times 20 \mathrm{~cm}+$ Pupuk Kandang Ayam & $4.62 \mathrm{~b}$ \\
$60 \mathrm{~cm} \times 25 \mathrm{~cm}+$ Kontrol & $4.69 \mathrm{~b}$ \\
$60 \mathrm{~cm} \times 25 \mathrm{~cm}+$ Pupuk Kandang Sapi & $4.68 \mathrm{~b}$ \\
$60 \mathrm{~cm} \times 25 \mathrm{~cm}+$ Pupuk Kandang Ayam & $5.02 \mathrm{a}$ \\
$50 \mathrm{~cm} \times 30 \mathrm{~cm}+$ Kontrol & $4.74 \mathrm{ab}$ \\
$50 \mathrm{~cm} \times 30 \mathrm{~cm}+$ Pupuk Kandang Sapi & $4.63 \mathrm{~b}$ \\
$50 \mathrm{~cm} \times 30 \mathrm{~cm}+$ Pupuk Kandang Ayam & $4.17 \mathrm{~b}$ \\
\hline \multicolumn{1}{c}{ BNT 5\% } & 0.17 \\
\hline
\end{tabular}

Keterangan : Angka-angka yang diikuti oleh huruf yang sama dalam kolom yang sama tidak berbeda nyata dengan uji BNT 5\%.

Pada Tabel 5. dapat dilihat bahwa pengamatan diameter tongkol tersebut menunjukkan interaksi antar perlakuan macam pupuk kandang dan pengaruh jarak tanam. Nilai tertinggi diperoleh pada perlakuan pupuk kandang ayam dan pengaruh jarak tanam $60 \mathrm{~cm} \times 25 \mathrm{~cm}$.

Hasil sidik ragam (Anova) menunjukkan bahwa terjadi pengaruh interaksi antara pemberian pupuk kandang dan jarak tanam terhadap diameter tongkol. Pemberian macam pupuk organik dan jarak tanam juga memberikan pengaruh utama pada masing-masing perlakuan terhadap diameter tongkol. Meskipun demikian, data (Tabel 5) menunjukkan bahwa diameter tongkol tanaman yang diberi pupuk kandang ayam cenderung lebih besar dari pada pertumbuhan tanaman yang diberikan perlakuan lainnya.

Pertumbuhan diameter tongkol jagung dipengaruhi oleh macam pupuk kandang. Pemberian pupuk kandang ayam memperlihatkan diameter tongkol yang lebih besar daripada pemberian pupuk kandang sapi atau yang tidak diberikan perlakuan. Perbedaan diameter tongkol ini bisa disebabkan oleh kandungan unsur hara dari masing-masing pupuk kandang, hal ini juga tidak terlepas dari faktor lingkungan yang mendukung antara lain cahaya, air, dan sebagainya. Kandungan fosfor yang tinggi pada pupuk kandang ayam akan mendorong pertambahan ukuran dari tongkol jagung.

\section{Berat Biji Kering}

Hasil analisa sidik ragam menunjukkan beda nyata pada perlakuan macam pupuk organik dan jarak tanam terhadap parameter berat biji kering. Perlakuan yang baik dapat dilihat pada Tabel 6. 
Tabel 6. Rata-rata Berat Biji Kering (g).

\begin{tabular}{lc}
\hline \multicolumn{1}{c}{ Perlakuan } & Rata-rata berat biji kering (g) \\
\hline $75 \mathrm{~cm} \times 20 \mathrm{~cm}+$ Kontrol & $89.26 \mathrm{bc}$ \\
$75 \mathrm{~cm} \times 20 \mathrm{~cm}+$ Pupuk Kandang Sapi & $89.79 \mathrm{abc}$ \\
$75 \mathrm{~cm} \times 20 \mathrm{~cm}+$ Pupuk Kandang Ayam & $83.60 \mathrm{c}$ \\
$60 \mathrm{~cm} \times 25 \mathrm{~cm}+$ Kontrol & $90.01 \mathrm{abc}$ \\
$60 \mathrm{~cm} \times 25 \mathrm{~cm}+$ Pupuk Kandang Sapi & $88.24 \mathrm{bc}$ \\
$60 \mathrm{~cm} \times 25 \mathrm{~cm}+$ Pupuk Kandang Ayam & $96.49 \mathrm{a}$ \\
$50 \mathrm{~cm} \times 30 \mathrm{~cm}+$ Kontrol & $84.15 \mathrm{bc}$ \\
$50 \mathrm{~cm} \times 30 \mathrm{~cm}+$ Pupuk Kandang Sapi & $90.57 \mathrm{ab}$ \\
$50 \mathrm{~cm} \times 30 \mathrm{~cm}+$ Pupuk Kandang Ayam & $89.48 \mathrm{bc}$ \\
\hline \multicolumn{1}{c}{ BNT 5\% } & 6.86 \\
\hline
\end{tabular}

$\overline{\text { Keterangan : Angka-angka yang diikuti oleh huruf yang sama dalam kolom yang sama tidak }}$ berbeda nyata dengan uji BNT 5\%.

Pada Tabel 6. dapat dilihat bahwa pengamatan parameter berat biji kering menunjukkan interaksi antar perlakuan. Dan terdapat beda nyata pada perlakuan macam pupuk organik dan jarak tanam. Nilai tertinggi diperoleh pada pemberian pupuk kangang ayam dan perlakuan jarak tanam $60 \mathrm{~cm} \times 25 \mathrm{~cm}$.

$$
\text { Hasil sidik ragam (Anova) }
$$
menunjukkan bahwa terjadi pengaruh interaksi antara pemberian macam pupuk kandang dan jarak tanam terhadap berat biji kering per tanaman. Pupuk kandang ayam memberikan pengaruh utama terhadap berat biji kering per tanaman. Dimana berat biji kering yang dihasilkan dari tanaman yang diberikan pupuk kandang ayam paling berat dibandingkan dengan tanaman yang tidak diberika pupuk kandang ataupun tanaman yang diberikan pupuk kandang sapi.

Pada perlakuan jarak tanam terdapat beda nyata. Yangmana memberikan pengaruh utama terhadap berat biji kering per tanaman. Yakni ditunjukkan bahwa tanaman yang ditanam dengan jarak $60 \mathrm{~cm}$ x $25 \mathrm{~cm}$ menghasilkan biji kering yang cenderung lebih berat dibandingkan dengan perlakuan lainnya menghasilkan biji kering yang paling ringan.

Maddonni et al, (2006) mengatakan bahwa jarak tanam yang sempit dapat meningkatkan produksi yang lebih besar. Pada dasarnya pengaplikasian jarak tanam bertujuan untuk meningkatkan hasil, dengan syarat tanaman tidak ternaungi atau batasan tanaman satu sama lain. Efek mandiri pemberian pupuk $\mathrm{N}$ mampu meningkatkan hasil dari tanaman. Hasil penelitian dari Balai Penelitian Tanaman Pangan Bogor, indeks panen pada tanaman jagung di daerah tropis sekitar 0,39 , begitu juga menurut Indradewa, et al (2005) bahwa indeks panen jagung berada di sekitar angka 0,39. Faktor lain yang mempengaruhi yaitu jarak tanam yang lebar karena mempengaruhi penyerapan sinar matahari dan fotosintesis berjalan optimal yang berdampak pada hasil fotosintat untuk pengisian biji.

Wati (2014) mengatakan bahwa, apabila fase vegetatif baik maka fase 
generative juga akan baik, karena fase vegetatif menyokong fase generatif. Semakin tinggi hasil fotosintesis maka semakin baik pula hasil tanaman. Hasil fotosintesis yang berupa karbohidrat akan diakumulasikan pada bagian generatif dan akumulasi karbohidrat yang dihasilkan sebagian besar digunakan untuk pembentukan biji.

Tabel 7. Rata-rata Berat 1000 Biji (g)

\section{Berat 1000 Biji}

Hasil analisa sidik ragam menunjukkan terdapat pengaruh beda sangat nyata pada perlakuan macam pupuk organik dan jarak tanam terhadap berat 1000 biji pada saat panen. perlakuan yang baik dapat dilihat pada Tabel 7 .
Perlakuan

$75 \mathrm{~cm} \times 20 \mathrm{~cm}+$ Kontrol

$75 \mathrm{~cm} \times 20 \mathrm{~cm}+$ Pupuk Kandang Sapi

$75 \mathrm{~cm} \times 20 \mathrm{~cm}+$ Pupuk Kandang Ayam

$60 \mathrm{~cm} \times 25 \mathrm{~cm}+$ Kontrol

$60 \mathrm{~cm} \times 25 \mathrm{~cm}+$ Pupuk Kandang Sapi

$60 \mathrm{~cm} \times 25 \mathrm{~cm}+$ Pupuk Kandang Ayam

$50 \mathrm{~cm} \times 30 \mathrm{~cm}+$ Kontrol

$50 \mathrm{~cm} \times 30 \mathrm{~cm}+$ Pupuk Kandang Sapi

$50 \mathrm{~cm} \times 30 \mathrm{~cm}+$ Pupuk Kandang Ayam
Rata-rata berat 1000 biji (g)

$349,80 \mathrm{c}$

350,17 c

$355,60 \mathrm{~b}$

$352,90 \mathrm{bc}$

374,90 a

$352,83 \mathrm{bc}$

$353,20 \mathrm{bc}$

$349,60 \mathrm{c}$

$\frac{\text { BNT 5\% }}{\text { Keterangan : Angka-angka yang diikuti oleh huruf yang sama dalam kolom yang sama tidak }}$
berbeda nyata dengan uji BNT $5 \%$

Hasil analisa sidik ragam menunjukkan bahwa terdapat interaksi antar perlakuan macam pupuk organik dengan jarak tanam. Dan menunjukkan pengaruh beda sangat nyata dari setiap perlakuan. Hasil terbaik yaitu pada perlakuan pupuk kandang ayam dengan pengaruh jarak tanam $60 \mathrm{~cm} \times 25 \mathrm{~cm}$.

Berdasarkan Tabel 7. Menunjukkan bahwa dari ketiga perlakuan tersebut hasil terbaik pada pengamatan bobot 1000 butir biji kering terletak pada perlakuan pupuk kandang ayam dengan jarak tanam $60 \mathrm{~cm} x$ $25 \mathrm{~cm}$. Jarak tanam maupun pemberian pupuk kandang yang diberikan telah menampakan pengaruh terhadap bobot 1000 biji, hal ini dapat diterangkan bahwa asimilat yang dihasilkan oleh tanaman dan digunakan untuk pembentukan biji cukup seimbang untuk perlakuan jarak tanam yang digunakan.

Ketersediaan unsur hara dari pemberian pupuk kandang sebagai salah satu bahan fotosintesis mengakibatkan proses fotosintesis berjalan lancar sehingga hasil fotosintesis (fotosintat) berupa karbohidrat sebagai bahan energi untuk pertumbuhan tanaman diakumulasikan ke dalam organ-organ tanaman. Hasil akumulasi karbohidrat tersebut dapat mempengaruhi bobot 1000 butir biji kering (Aini Indrasari 2006).

Menurut Rosmarkam (2002), pemindahan sukrosa dan metabolisme 
karbohidrat pada daun dipengaruhi oleh phospat. Proses utama penyusunan energi tinggi phospat diperlukan sukrosa dan heksosa (ATP dan ADP). Oleh karena itu, phospat diperlukan dalam sel dan waktu penyusunan karbohidrat. Sebagian phospat sangat berkaitan dan bergabung dengan pati, terutama pada tanaman biji-bijian dan serelia.

Phospat dibutuhkan dan sangat penting dalam fase vegetatif dan generatif, sebagai penentu hasil tanaman. Karena phospat berperan dalam meningkatkan perkembangan akar, peningkatan kadar phospat dalam tanaman akan diikuti dengan meningkatnya serapan unsur hara lain, sehingga fotosintesis juga meningkat. Dengan demikian fotosintesis yang dihasilkan juga lebih besar sehingga meningkatkan pasokan berat kering ke dalam biji,

\section{KESIMPULAN}

Dari hasil penelitian yang telah dilakukan, perlakuan macam pupuk organik dan jarak tanam terhadap pertumbuhan dan produksi tanaman jagung (Zea mays L.) dapat disimpulkan bahwa :

Terdapat interaksi antara perlakuan pupuk kandang ayam dan jarak tanam 60 $\mathrm{cm} \times 25 \mathrm{~cm}$ terhadap pertumbuhan dan produksi tanaman jagung (Zea mays L.)

Menunjukkan pengaruh nyata pada perlakuan tinggi tanaman umur 42 dan 56 hst, panjang tongkol, berat biji kering dan berat 1000 biji. Terdapat beda sangat nyata pada perlakuan pengamatan tinggi tanaman umur 28 hst, jumlah daun 42 dan 56 hst, diameter tongkol. Terdapat tidak beda nyata pada pengamatan jumlah daun umur 28 hst.

\section{SARAN}

Penelitian ini dapat dilanjutkan dengan perlakuan pupuk kandang ayam dan jarak tanam yang lebih lebar lagi guna meningkatkan pertumbuhan dan produksi tanaman jagung (Zea mays L.).

\section{DAFTAR PUSTAKA}

Anonymous.

2012.

http://www.sarjanaku.com/2012 104/06macam-macam-pupuk organik-dan-anorganik.html/ di akses pada tanggal 23 Juni 2019.

Andoko, A. 2012. Budidaya Padi Secara Organik. Penebar Swadaya. Jakarta $96 \mathrm{hlm}$.

Aini Indrasari dan Abdul Syukur. 2006. Kajian Macam Pupuk Kandang dan Unsur Hara Mikro Terhadap Pertumbuhan Jagung Pada Ultisol yang di Kapur. Jurusan Tanah Fakultas Pertanian UGM, Yogyakarta.

Basuki, 2000. Respon Pertumbuhan Kacang Tanah (Arachis hypogaea L.) dan pemberian kompos azolla. Skripsi S1 Fakultas Pertanian Universitas Brawijaya. Malang. 33 hal.

Indradewa D, Kastono D, S. Yasmin. 2005. Kemungkinan Peningkatan Hasil Jagung Dengan Pemendekan Batang. Ilmu Pertanian. Vol. 12 No.2 Hal . 117-124.

Maddoni GA, Cirilo and Otegui ME. 2006. Row Widht and Maize Grainyield. Agron. J.98:1532-1543.

Rachman. (2008). Daun tanaman puring efektif serap timbal. Laporan penelitian UII. Diakses tanggal 17 Januari 2009 dari: http://langitlangit.com. 
Rosmarkam, A. dan Yuwono, N. 2002. Ilmu Kesuburan Tanah. Kanikus. Yogyakarta.

Sidar. 2010. Kajian Macam Pupuk Organik Terhadap Sifat Kimia Tanah dan Hasil Tanaman Jagung Manis (Zeamays Saccharata) Pada Fluventic Eutrupdepts asal Jatinangor Kabupaten Sumedang. Artilkel Ilmiah . http:search Pdf.//kompos-sampahkota/Sidar/html. Diakses pada tanggal 18 Mei 2010. Pekanbaru.

Sudarsana R. 2000. Budi Daya Tanaman Jagung. Pustaka Buana. Bandung. Hal 154.

Supriono, 2000. Pengaruh pupuk anorganik dan Jarak Tanam Terhadap Pertumbuhan dan Hasil Kedelai Kultivar Sindoro. Agrosains Volume 2 No 2, 2000.

Sutedjo, M. 2002. Pupuk dan Cara Pemupukan. Rineka Cipta, Jakarta.

Wati, Y.T. 2014. Pengaruh Aplikasi Biourin Pada Pertumbuhan Dan Hasil Tanaman Bawang Merah (Allium ascalonicum L.). Skripsi. Jurusan Budidaya Pertanian, Fakultas Pertanian, Universitas Brawijaya. Malang 